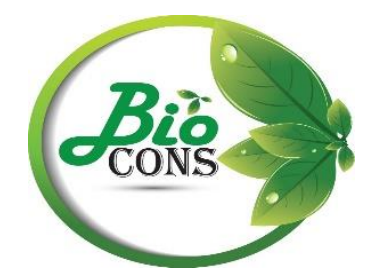

\title{
EFEKTIVITAS KOMPOS ECENG GONDOK (Eichornia crassipes) TERHADAP PRODUKTIVITAS TANAMAN CABAI RAWIT DI KABUPATEN SITUBONDO (Capsicum frutescens $L$.)
}

\section{EFFECTIVENESS OF HYACINTH COMPOST (Eichornia crassipes) AGAINST THE PRODUCTIVITY OF CAYENNE PEPPER PLANTS IN SITUBONDO REGENCY (Capsicum frutescens $L$.}

\author{
Lila Maharani* \\ Prodi Pendidikan Biologi, FKIP, Universitas PGRI Argopuro Jember \\ *Email : lilarani82@gmail.com
}

\begin{abstract}
ABSTRAK
Cabai rawit (Capsicum frutescens L.) merupakan salah satu komoditas sayuran yang keberadaannya tidak dapat ditinggalkan oleh masyarakat Indonesia dalam kehidupan sehari-hari. Namun, masih ada permasalahan yang muncul dalam budidaya cabai rawit di Kabupaten Situbondo yaitu turunnya produktivitas cabai rawit disebabkan oleh tingkat kesuburan tanah, serangan hama dan penyakit yang menyebabkan gagal panen. Dalam rangka meningkatkan produktivitas cabai rawit, dilakukan pemanfaatan limbah eceng gondok yang berpotensi dapat dijadikan kompos. Penelitian ini bertujuan untuk mengetahui efektifitas kompos eceng gondok terhadap produktivitas cabai rawit. Jenis penelitian ini menggunakan penelitian eksperimental murni dengan desain Rancangan Acak Kelompok (RAK) dengan 4 perlakuan konsentrasi kompos eceng gondok yaitu 0\%, 20\%, 40\%, 80\%, masingmasing diulang 8 kali. Sampel penelitian dipilih dengan teknik simple random sampling. Parameter yang diamati yaitu tinggi tanaman $(\mathrm{cm})$, jumlah cabang, usia bunga pertama, jumlah bunga, jumlah buah, dan berat buah (gram). Data hasil penelitian dianalisis menggunakan Uji Univariat dengan uji lanjut Duncan pada taraf kepercayaan 95\%. Hasil penelitian ini menunjukkan bahwa pemberian kompos eceng gondok berpengaruh nyata terhadap parameter tinggi tanaman, jumlah cabang, usia bunga pertama, jumlah buah dan berat buah, kecuali pada parameter jumlah bunga yang menunjukkan hasil tidak berbeda nyata. Hasil uji lanjut Duncan menunjukkan bahwa pemberian kompos eceng gondok konsentrasi $80 \%$ memberikan hasil terbaik pada semua parameter pengamatan.
\end{abstract}

Kata Kunci : Cabai Rawit, Eceng Gondok, Kompos, Produktivitas, Sumber Belajar. 


\begin{abstract}
Cayenne pepper (Capsicum frutescens L.) is one of the vegetable commodities whose existence cannot be abandoned by Indonesian people in their daily life. However, there are still problems that arise in the cultivation of cayenne pepper in Situbondo Regency, namely the decline in the productivity of cayenne pepper caused by the level of soil fertility, pests and diseases that cause crop failure. In order to increase the productivity of cayenne pepper, water hyacinth waste is utilized which has the potential to be used as compost. This study aims to determine the effectiveness of water hyacinth compost on the productivity of cayenne pepper. This type of research used a pure experimental study with a Randomized Block Design design with 4 treatments of water hyacinth compost concentration, namely $0 \%, 20 \%, 40 \%, 80 \%$, each repeated 8 times. The research sample was selected by simple random sampling technique. Parameters observed were plant height $(\mathrm{cm})$, number of branches, age of first flower, number of flowers, number of fruit, and fruit weight (grams). The research data were analyzed using the Univariate Test with Duncan's advanced test at a 95\% confidence level. The results of this study showed that the application of water hyacinth compost had a significant effect on the parameters of plant height, number of branches, age of first flower, number of fruits and fruit weight, except for the number of flowers parameters which showed no significant difference. Duncan's further test results showed that the application of $80 \%$ concentration of water hyacinth compost gave the best results on all observation parameters.
\end{abstract}

Keywords: Cayenne pepper, Water Hyacinth, Compost, Productivity, Learning Resources.

\title{
PENDAHULUAN
}

Cabai rawit (Capsicum frutescens L.) merupakan salah satu komoditas sayuran yang keberadaannya tidak dapat ditinggalkan oleh masyarakat Indonesia dalam kehidupan seharihari. Cabai rawit digunakan sebagai bahan bumbu dapur, industri bubuk cabai, sampai industri farmasi. Permintaan yang tinggi terhadap cabai rawit membutuhkan usaha untuk meningkatkan produktivitas cabai rawit. Pada tahun 2017, produktivitas cabai rawit di Kabupaten Situbondo mengalami penurunan mencapai 3.265 kuintal menjadi 351 kuintal di bulan April yang disebabkan menurunnya kesuburan tanah, serangan hama dan penyakit yang menyebabkan gagal panen.

Salah satu alternatif usaha untuk mengatasi hal tersebut adalah dengan melakukan pemupukan. Pupuk dapat dibuat dengan memanfaatkan limbah yang ada di sekitar kita. Pemanfaatan limbah untuk pembuatan pupuk organik merupakan langkah positif dalam penerapan budidaya pertanian yang berkelanjutan dan berdampak bagus terhadap kelestarian lingkungan.

Eceng Gondok (Eichhornia crassipes) mengandung beberapa unsur hara makro dan mikro yang sangat dibutuhkan untuk pertumbuhan tanaman. Beberapa unsur hara yang terdapat pada eceng gondok, antara lain; Al (Alumunium), Cd (Kadmium), $\mathrm{Cu}$ (Tembaga), $\mathrm{Fe}$ (Besi), Mn (Mangan), Pb (Timbal) dan $\mathrm{Zn}$ (Seng). Unsur hara yang termasuk kedalam unsur hara mikro yaitu unsur hara yang diperlukan dalam jumlah yang besar yaitu C-organik, N-total, P (Fospor), K (Kalium), Ca (Kalsium) 
dan Mg (Magnesium) (Nurhalimah, 2017). Berdasarkan hasil obeservasi di Desa Curah Cottok Wisata Waduk Pitaloka Kabupaten Situbondo, tanaman eceng gondok menjadi limbah dan sangat mengganggu aktivitas manusia.

Berdasarkan latar belakang tersebut, Penulis berinisiatif untuk memanfaaatan limbah eceng gondok untuk dijadikan kompos. Penelitian ini bertujuan untuk mengetahui efektivitas kompos eceng gondok terhadap produktivitas cabe rawit.

\section{METODE}

Penelitian ini dilaksanakan di Kabupaten Situbondo. Penelitian ini dilaksanakan dari bulan Agustus sampai dengan Desember 2019.

Alat-alat yang digunakan antara lain; drum, serok, timbangan, ember, dan cangkul. Bahan-bahan yang digunakan antara lain; eceng gondok $20 \mathrm{~kg}$, dedak $0.625 \mathrm{~kg}$, sekam $3.75 \mathrm{~kg}$, $50 \mathrm{ml} \mathrm{EM} 4$, gula merah $200 \mathrm{~g}$ dan air 1 liter.

Kompos dibuat dengan cara mencampurkan semua bahan, memasukan eceng gondok setinggi $60 \mathrm{~cm}$ pada drum/ember plastik, menaburkan sekam, dedak dan EM4 yang sudah dicampur dengan gula dan air secara merata pada timbunan eceng gondok. Hal tersebut dilakukan secara berulang hingga bahan habis. Proses pembalikan bahan pupuk dilakukan setelah 7 hari. Kompos dapat siap digunakan dengan ciri kompos berwarna coklat kehitaman, bau tidak menyengat dan tumbuh jamur berwarna putih (Yanuarismah, 2012 dan Sri Utami,dkk 2016).

Penelitian ini menggunakan Rancangan Acak Kelompok (RAK) faktor tunggal yang terdiri 4 perlakuan konsentrasi $(0 \%, 20 \%, 40 \%$, dan 80\%), antara lain:

$\mathrm{P} 1$ : Kompos enceng gondok $0 \%+1 \mathrm{~kg}$ tanah sebagai kontrol negatif

P2 : Kompos enceng gondok 20\% (200 gr) + 800 gr tanah

P3 : Kompos enceng gondok 40\% (400 gr) + 600 gr tanah

P4 : Kompos enceng gondok $80 \%(800$ gram $)+200$ gr tanah.

Setiap perlakuan diulang sebanyak 8 kali ulangan, dengan 4 perlakuan sehingga didapat sebanyak 32 satuan percobaan. Parameter yang diamati adalah tinggi tanaman $(\mathrm{cm})$, jumlah cabang, usia bunga pertama, jumlah bunga, jumlah buah, dan berat buah (gram). Data hasil penelitian diuji dengan Uji Univariat yang dilanjutkan dengan uji Duncan menggunakan aplikasi SPSS. 


\section{HASIL DAN PEMBAHASAN}

Hasil pengamatan dalam penelitian ini meliputi tinggi $(\mathrm{cm})$, jumlah cabang, usia bunga pertama, jumlah bunga, jumlah buah, dan berat buah (gram) seperti tertera dalam Tabel 1. ampai sampai Tabel 6. berikut ini.

Tabel 1. Hasil pengukuran pertambahan tinggi tanaman $(\mathrm{cm})$.

\begin{tabular}{ll}
\hline \multicolumn{1}{c}{ Perlakuan } & Rerata Perlakuan \\
\hline Kompos eceng gondok 0\% & $29.97 \mathrm{a}$ \\
\hline Kompos eceng gondok $20 \%$ & $31.03 \mathrm{a}$ \\
\hline Kompos eceng gondok $40 \%$ & $32.71 \mathrm{a}$ \\
\hline Kompos eceng gondok $80 \%$ & $38.50 \mathrm{~b}$
\end{tabular}

Keterangan : angka yang diikuti oleh huruf yang berbeda pada kolom yang sama menunjukkan terdapat perbedaan yang nyata $(\mathrm{P}<0.05)$.

Hasil uji Univariat menunjukkan bahwa perlakuan kompos berpengaruh nyata pada parameter tinggi tanaman. Hasil uji lanjut Duncan (Tabel 1.) menunjukkan bahwa perlakuan kompos $80 \%$ memberikan pengaruh terbaik terhadap tinggi tanaman dibandingkan perlakuan lainnya.

Hal ini terjadi dapat terjadi karena pupuk kompos eceng gondok mengandung unsur hara yang dapat memacu pertumbuhan meristem apikal sehingga tanaman bertambah panjang (Utami dkk, 2016). Pendapat tersebut sesuai dengan pernyataan Kusrinah et al., (2016) yang menyatakan bahwa bahan organik eceng gondok memiliki kandungan hara yang cukup bagi tanaman, sehingga menyebabkan pertambahan tinggi pada tanaman. Pada perlakuan P1, P2, dan P3 pertambahan tinggi tidak terlalu besar karena kemungkinan unsur hara yang diserap oleh tanaman relatif sedikit. Pendapat tersebut sesuai dengan pendapat Nugroho (2011) yang menyatakan bahwa untuk tumbuh dan berkembang tanaman memerlukan unsur hara $\mathrm{N}, \mathrm{P}$ dan $\mathrm{K}$ dalam jumlah banyak, sehingga tanaman akan tumbuh subur.

Pada parameter jumlah cabang hasil uji univariat juga menunjukkan hasil berbeda nyata. Hasil uji lanjut Duncan menunjukkan bahwa pemupukan kompos $80 \%$ memberikan pengaruh terbaik terhadap jumlah cabang dibandingkan perlakuan lainnya (Tabel 2.).

Tabel 2. Hasil penghitungan jumlah cabang

\begin{tabular}{lc}
\hline \multicolumn{1}{c}{ Perlakuan } & Rerata Perlakuan \\
\hline Kompos eceng gondok 0\% & $25.25 \mathrm{a}$ \\
\hline Kompos eceng gondok 20\% & $28.62 \mathrm{ab}$ \\
\hline Kompos eceng gondok $40 \%$ & $31.00 \mathrm{~b}$ \\
\hline Kompos eceng gondok $80 \%$ & $40.50 \mathrm{c}$ \\
\hline
\end{tabular}

Keterangan : angka yang diikuti oleh huruf yang berbeda pada kolom yang sama menunjukkan terdapat perbedaan yang nyata $(\mathrm{P}<0.05)$. 
Hal tersebut disebabkan karena pengaruh pemberian unsur hara pada tanaman. Pemberian kompos eceng gondok menambah ketersediaan hara, khususnya N, P dan K di dalam tanah. Menurut Subhan dkk (2009), menyatakan bahwa Nitrogen merupakan komponen dasar dalam sintesis protein, bagian dari klorofil dan berperan dalam proses fotosintesis yang akan digunakan dalam setiap proses pertumbuhan termasuk dalam pembentukan cabang tanaman. Sedangkan pada perlakuan P1,P2, dan P3 jumlah cabang pada tanaman relatif lebih sedikit yang disebabkan unsur hara yang diserap tanaman kurang optimal. Pendapat tersebut diperkuat oleh pendapat Tampubolon (2012) yang menyatakan bahwa tanaman membutuhkan unsur hara atau nutrisi selama pertumbuhannya agar dapat tumbuh dan berkembang dengan baik.

Sedangkan pada parameter usia bunga pertama, perlakuan kompos juga memberikan pengaruh yang nyata. Hasil uji lanjut Duncan pada parameter ini tertera pada Tabel 3. Sebagai berikut:

Tabel 3. Hasil pengamatan usia bunga pertama

\begin{tabular}{lc}
\hline \multicolumn{1}{c}{ Perlakuan } & Rerata Perlakuan \\
\hline Kompos eceng gondok 0\% & $58.12 \mathrm{c}$ \\
\hline Kompos eceng gondok 20\% & $57.12 \mathrm{bc}$ \\
\hline Kompos eceng gondok $40 \%$ & $56.62 \mathrm{ab}$ \\
\hline Kompos eceng gondok $80 \%$ & $55.62 \mathrm{a}$ \\
\hline
\end{tabular}

Keterangan : angka yang diikuti oleh huruf yang berbeda pada kolom yang sama menunjukkan terdapat perbedaan yang nyata $(\mathrm{P}<0.05)$.

Pada parameter usia bunga pertama, perlakuan yang menghasilkan bunga dengan usia tercepat dihasilkan oleh perlakuan kompos eceng gondok $80 \%$. Sedangkan perlakuan lainnya menunjukkan usia berbunga yang lebih lama. Usia berbunga terlama diperoleh pada perlakuan tanpa pemupukan (kontrol negatif). Arnanto dkk (2013) menyatakan bahwa perbedaan umur berbunga pada tiap tanaman dapat terjadi akibat perbedaan jumlah unsur hara yang diserap oleh tanaman. Pada perlakuan P1, P2, dan P3 mengalami proses pembentukan bunga yang lebih lama. Hal tersebut disebabkan rendahnya unsur hara yang diserap oleh tanaman. Kandungan $\mathrm{P}$ (fosfor) yang diserap relatif sedikit sehingga pembentukan bunga lebih lama. Pendapat tersebut didukung oleh Lingga (2007), yang menyatakan bahwa unsur P diperlukan untuk tanaman dalam mempercepat pertumbuhan generatif (bunga dan buah), sehingga kekurangan unsur $\mathrm{P}$ dapat menurunkan produktivitas tanaman.

Pada parameter jumlah bunga, hasil uji Univariat menunjukkan bahwa perlakuan kompos eceng gondok tidak berpengaruh nyata. Hal ini diperkuat oleh hasil uji lanjut Duncan dimana semua perlakuan memiliki notasi yang sama atau tidak berbeda nyata (Tabel 4.). 
Tabel 4. Hasil penghitungan jumlah bunga

\begin{tabular}{ll}
\hline \multicolumn{1}{c}{ Perlakuan } & Rerata Perlakuan \\
\hline Kompos eceng gondok 0\% & $4.75 \mathrm{a}$ \\
\hline Kompos eceng gondok $20 \%$ & $5.00 \mathrm{a}$ \\
\hline Kompos eceng gondok $40 \%$ & $4.25 \mathrm{a}$ \\
\hline Kompos eceng gondok $80 \%$ & $6.50 \mathrm{a}$ \\
\hline
\end{tabular}

Keterangan : angka yang diikuti oleh huruf yang sama pada kolom yang sama Menunjukkan tidak ada perbedaan yang nyata $(\mathrm{P}>0.05)$.

Hasil tersebut disebabkan oleh gugurnya bunga pada setiap perlakuan pada saat berlangsungnya proses penelitian. Pada kasus ini, faktor lingkungan diduga berpengaruh terhadap jumlah bunga. Hal ini didukung oleh Supriyanti (2013) yang menyatakan bahwa budidaya cabai pada musim hujan mengakibatkan bunga rontok saat turun hujan. Walaupun hasil semua perlakuan tidak berbeda nyata, namun secara angka, pada konsentrasi $80 \%$ bunga cabai dapat mempertahankan diri dari kerontokannya dibandingkan konsentrasi lainnya. Hal tersebut disebabkan disebabkan kandungan unsur hara P (Fosfor) yang ada didalam kompos eceng gondok. Hal ini sesuai dengan pernyataan Lingga dan Marsono (2007) menyatakan bahwa unsur K berfungsi untuk meperkuat bagian tubuh tanaman seperti daun, bunga dan buah agar tidak mudah gugur, meningkatkan daya tahan tanaman terhadap kekeringan dan penyakit, serta meningkatkan mutu dari biji buah.

Sedangkan pada parameter jumlah buah, hasil uji Univariat menunjukkan hasil berbeda nyata. Hasil uji lanjut Duncan menunjukkan bahwa perlakuan pemupukan kompos eceng gondok $80 \%$ menghasilkan jumlah buah terbanyak di antara perlakuan lainnya (Tabel 5.).

Tabel 5. Hasil penghitungan jumlah buah

\begin{tabular}{lc}
\hline \multicolumn{1}{c}{ Perlakuan } & Rerata Perlakuan \\
\hline Kompos eceng gondok 0\% & $9.00 \mathrm{a}$ \\
\hline Kompos eceng gondok 20\% & $9.25 \mathrm{a}$ \\
\hline Kompos eceng gondok $40 \%$ & $11.00 \mathrm{ab}$ \\
\hline Kompos eceng gondok $80 \%$ & $14.87 \mathrm{~b}$ \\
\hline
\end{tabular}

Keterangan : angka yang diikuti oleh huruf yang berbeda pada kolom yang sama menunjukkan ada perbedaan yang nyata $(\mathrm{P}<0.05)$.

Hal ini disebabkan karena ketersediaan unsur hara untuk membantu tanaman dalam memproduksi buah. Pendapat tersebut didukung oleh Ripangi (2012), yang menyatakan bahwa kompos yang banyak mengandung unsur $\mathrm{P}$ sangat baik dalam penambahan nutrisi sewaktu terjadi pembentukan buah. Pada perlakuan P1, P2, dan P3 tanaman menghasilkan buah lebih 
sedikit yang disebabkan rendahnya konsentrasi unsur hara yang diberikan pada tanaman. Ketersediaan unsur hara sangat penting pada masa generatif. Hal tersebut diukung oleh Wiryono (2010), yang menyatakan bahwa pertumbuhan tanaman akan optimal jika lingkungan tumbuh menyediakan unsur hara dalam jumlah yang cukup di dalam tanah.

Pada parameter berat buah cabai rawit, hasil uji Univariat juga menghasilkan hasil berbeda nyata. Hasil uji lanjut Duncan juga menunjukkan bahwa perlakuan kompos eceng gondok $80 \%$ menghasilkan berat buat paling tingga daripada perlakuan lainnya (Tabel 6.).

Tabel 6. Hasil Penghitungan berat buah (gram)

\begin{tabular}{ll}
\hline Perlakuan & Rerata Perlakuan \\
\hline Kompos eceng gondok $0 \%+8 \mathrm{~kg}$ tanah & $9.15 \mathrm{a}$ \\
\hline Kompos eceng gondok $20 \%+8 \mathrm{~kg}$ tanah & $8.90 \mathrm{a}$ \\
\hline Kompos eceng gondok $40 \%+8 \mathrm{~kg}$ tanah & $10.51 \mathrm{a}$ \\
\hline Kompos eceng gondok $80 \%+8 \mathrm{~kg}$ tanah & $17.11 \mathrm{c}$ \\
\hline
\end{tabular}

Keterangan : angka yang diikuti oleh huruf yang berbeda pada kolom yang sama menunjukkan terdapat perbedaan yang nyata $(\mathrm{P}<0.05)$.

Hasil tersebut disebabkan oleh pemberian pupuk kompos eceng gondok yang semakin tinggi dapat meningkatkan berat segar tanaman cabai rawit. Pendapat tersebut didukung oleh Suharja (2009), yang menyatakan bahwa peningkatan kandungan Nitrogen tanaman dapat berpengaruh terhadap fotosintesis, khususnya pada pembentukkan klorofil sehingga meningkatkan fotosintat (bobot segar, bobot kering, dan bobot buah cabai) yang dihasilkan. Perlakuan P1, P2, dan P3 berat buahnya relatif sedikit disebabkan oleh unsur hara yang diberikan terhadap tanaman masih kurang. Pendapat tersebut diperkuat oleh Lakitan (2012), yang menyatakan bahwa kecukupan kebutuhan hara tanaman, baik unsur hara makro maupun mikro akan meningkatkan pertumbuhan tanaman dan sebaliknya, jika kebutuhan hara tanaman kurang mengakibatkan pertumbuhan tanaman terhambat.

\section{SIMPULAN}

Hasil penelitian ini menunjukkan bahwa pemberian kompos eceng gondok berpengaruh nyata terhadap parameter tinggi tanaman, jumlah cabang, usia bunga pertama, jumlah buah dan berat buah, kecuali pada parameter jumlah bunga yang menunjukkan hasil tidak berbeda nyata. Hasil uji lanjut Duncan menunjukkan bahwa pemberian kompos eceng gondok konsentrasi $80 \%$ memberikan hasil terbaik pada semua parameter pengamatan. 


\section{DAFTAR PUSTAKA}

Arnanto, D., Basuki dan Respatijarti. (2013). Uji Toleransi Salinitas terhadap Sepuluh Genotip F1 Tomat. Jurnal Produksi Tanaman, 1 (5),415 - 421.

Kusrinah, Alwiyah, N., Nur, H. (2016). Pelatihan dan Pendampingan Pemanfaatan Eceng Gondok (Eichhornia crassipes) menjadi Pupuk Kompos Cair untuk Mengurangi Pencemaran Air dan Meningkatkan Ekonomi Masyarakat Desa Karangkimpul Kelurahan Kaligawe Kecamatan Gayamsari Kotamadya Semarang. DIMAS, 16 (1), 27-48.

Lakitan. (2012). Dasar-dasar Fisiologis Tumbuhan. Rajawali Press. Jakarta.

Lingga, P. dan Marsono. (2007). Petunjuk Penggunaan Pupuk. Penebar Swadaya. Jakarta.

Nurhalimah. (2017). Pengujian Kandungan Unsur Hara pada Eceng Gondok (Eichornia crassipes) dari Danau Toba. Skripsi. Fakultas Kehutanan Universitas Sumatera Utara.

Nugroho. (2011). Peran Konsentrasi Pupuk Daun dan Dosis Pupuk Kalium terhadap Hasil Tanaman Tomat (Lycopersicum esculentum Mill). Politeknosains; Edisi Khusus Dies Natalis Fakultas Pertanian Universitas Boyolali, 1-9.

Ripangi. (2012). Bertanam Cabai di Lahan dan Pot. Javalitera. Yogyakarta.

Subhan, Nurtika N., Gunadi. N. (2009). Respon Tanaman Tomat terhadap Penggunaan Pupuk Majemuk NPK 15-15-15 pada Tanah Latosol Pada Musim Kemarau. Jurnal Hortikultura, 19(1), 40-48.

Suharja. (2009). Biomassa, Kandungan Klorofil dan Nitrogen Daun Dua Varietas Cabai pada Berbagai Perlakuan. Tesis. Universitas Sebelas Maret. Surakarta.

Supriyanti, A. (2013). Perakitan dan Seleksi Tanaman Cabai (Capsicum annuum L.) Tahan CMV (Cucumber Mozaik Virus). Makalah Seminar. Jurusan Budidaya Pertanian Fakultas Pertanian. Universitas Gadjah Mada. Yogyakarta. 35 hlm.

Tampubolon, E. (2012). Pemanfaatan Limbah Ternak sebagai Pupuk Cair Organik untuk Meningkatkan Pertumbuhan dan Produksi Selada (Lactuca sativa var. crispa). Skripsi. Fakultas Pertanian IPB.

Utami, S., Darmawati, J.S., dan M. Yunus. (2016). Aplikasi Pupuk Kompos Eceng Gondok dan Mikoriza Berpenagruh Terhadap Pertumbuhan Tanaman Tembakau Deli (Nicotiana tabaccum L. ). Jurnal Pertanian Tropik, 3, (3), 219-229.

Wiryono. (2012). Pemanfaatan Biochar dan Biokompos dalam Meningkatkan Hasil Tanaman Jagung (Zea mays L.) dan Perubahan Sifat Kimia Tanah Inceptisol Kabupaten Lombok Timur. Tesis. Program Studi Magister Pengelolaan Sumberdaya Lahan Kering, Program Pascasarjana Universitas Mataram. 